\title{
Carbon Nanotube Filters for Removal of Air Pollutants from Mobile Sources
}

\author{
L. Romero-Guzmán' ${ }^{1}$ L. R. Reyes-Gutiérrez ${ }^{2}$, E. T. Romero-Guzmán ${ }^{3 *}$, E. Savedra-Labastida1,3 \\ ${ }^{1}$ Universidad Autónoma del Estado de México, Toluca, México \\ ${ }^{2}$ División de Ciencias Básicas e Ingeniería, Departamento de Recursos de la Tierra, Universidad Autónoma Metropolitana-Lerma \\ (UAM-L), Lerma, México \\ ${ }^{3}$ Instituto Nacional de Investigaciones Nucleares, Ocoyoacác, México \\ Email: arq_lilianarg@hotmail.com, 1.reyes@correo.ler.uam.mx, *elizabeth.romero@inin.gob.mx, sav_erika@hotmail.com
}

How to cite this paper: Romero-Guzmán, L., Reyes-Gutiérrez, L.R., Romero-Guzmán, E.T. and Savedra-Labastida, E. (2018) Carbon Nanotube Filters for Removal of Air Pollutants from Mobile Sources. Journal of Minerals and Materials Characterization and Engineering, 6, 105-118.

https://doi.org/10.4236/jmmce.2018.61009

Received: November 7, 2017

Accepted: January 28, 2018

Published: January 31, 2018

Copyright $\odot 2018$ by authors and Scientific Research Publishing Inc. This work is licensed under the Creative Commons Attribution International License (CC BY 4.0)

http://creativecommons.org/licenses/by/4.0/

\section{(c) (i) Open Access}

\begin{abstract}
The aim of this work was the assessment of the removal of air pollutants from mobile sources by commercial carbon nanotubes (CNTs). For this, the nanomaterial was characterized by different techniques: SEM, EDS, TEM, XRD, BET, and Raman. Subsequently, the CNTs were packed in a stainless steel filters which was designed from different prototypes that were developed during the investigation. Tests were performed in the TO-913 Verificenter Macrover Auto SAQ. Inc. de CV. The results revealed that particle type sand CNTs loading had greater effects on the efficiencies than the membrane type sand pore sizes tested. When collecting $\mathrm{NO}_{x}$, the efficiencies were observed relatively lower, below $20 \%$ for loadings of $0.3-1.5 \mathrm{mg} / \mathrm{cm}^{2}$. The studied CNTs were multi-walled: two layers, show a nonlinear growth and morphology varied since they are of different diameters and longitudes, it was observed that half of the nanotubes were coated with amorphous carbon. The composition is mainly carbon and oxygen, iron is also present. The adsorption capacity of CNTs was significantly influenced by the different aspects, like model, brand, fuel, year and the conditions of each car. The removal efficiencies of CNTs filters were shown to range from $10 \%$ to $95 \%$ in average for the CNTs loadings of $0.2-1.6 \mathrm{mg} / \mathrm{cm}^{2}$. When collecting $\mathrm{CO}, \mathrm{CO}_{2}, \mathrm{NO}_{x}, \mathrm{HC}$, the efficiencies were shown to range from $5 \%$ to $60 \%$ given similar CNTs loadings used.
\end{abstract}

\section{Keywords}

Carbon Nanotubes, $\mathrm{NO}_{\mathrm{x}}$, Air Contamination, Removal Efficiency, Mobile

\section{Introduction}

The atmosphere is essential for life so their disorders have a major impact on 
man and other living beings and, in general, worldwide, the health, environmental, and economic impacts of air pollution are significant [1]. Nowadays, emission of greenhouse gases due to incomplete combustion of fossil fuels which causes global warming is one of the most important environmental problems in the world [2]. Air pollutants, such as carbon monoxide (CO), sulphur dioxide $\left(\mathrm{SO}_{2}\right)$, nitrogen oxides $\left(\mathrm{NO}_{\mathrm{x}}\right)$, Volatile Organic Compounds (VOCs), ozone $\left(\mathrm{O}_{3}\right)$, heavy metals, and respirable particulate matter $\left(\mathrm{PM}_{2.5}\right.$ and $\left.\mathrm{PM}_{10}\right)$, differ in their chemical composition, reaction properties, emission, time of disintegration and ability to diffuse in long or short distances [3].

Gaseous pollutants contribute to a great extent in composition variations of the atmosphere and are mainly due to incomplete combustion of fossil fuels [4]. A major source of air pollution in urban areas is the incomplete combustion of diesel and gasoline fuels in cars, buses, trucks and other on-road transportation sources (aircrafts) [5]. The main anthropogenic sources are mobile and stationary combustion sources. As a result of fuel incomplete combustion, automobiles emit various compounds into the atmosphere in the form of exhaust. Mobile sources have a significant influence on both $\mathrm{NO}_{\mathrm{x}}$ and VOC pollution. Nitrogen oxides are emitted as NO which rapidly reacts with ozone or radicals in the atmosphere forming $\mathrm{NO}_{2}$. Moreover, ozone in the lower atmospheric layers is formed by a series of reactions involving $\mathrm{NO}_{2}$ and volatile organic compounds, a process initiated by sun light. $\mathrm{CO}$, on the other hand, is a product of incomplete combustion. Its major source is road transport too. A major class of compounds that fuel combustion and especially incomplete combustion processes for energy production and road transport are the major source of emission are the so called volatile organic compounds (VOCs). This is a class of compounds, which includes chemical species of organic nature such as benzene.

The complexity of spatial and temporal distributions of vehicle emissions/ activities and the mobility of vehicles make it very hard to quantify the proportions of ambient air pollutant concentrations attributable to on-road mobile sources [6]. Ambient concentrations of pollutants are correlated with emissions, but the contribution to ambient air quality of on road mobile sources is not necessarily equal to their contribution to regional emissions. This is true for several reasons such as the distribution of other pollution sources and regional topology, as well as meteorology.

Long-term epidemiologic studies have reported an increased risk of all causes of mortality, cardiopulmonary mortality, and lung cancer mortality associated with increasing exposures to air pollution. Adverse reproductive effects (risk for low birth weight) have also recently been reported in Eastern Europe and North America. Daily increments in the concentrations of air pollutants are associated, in the short term, an increase in the number of deaths in cities [7].

For the developing countries there have been few or no monitoring programs to demonstrate the long term development, but in many cases there is indication of a rapidly deteriorating environment [8]. In Mexico, state or local agencies can 
have more restrictive standards. The vehicle emissions verification program in Mexico is intended to reduce air pollution emissions from vehicles by ensuring that those vehicles with high emission levels are correctly repaired. In Mexico, to date, only the Mexico City has established extensive standards more restrictive and these only for gasoline powered automobiles. For the gasoline-engine equipped vehicle population, the emissions verification program targets four types of pollution: hydrocarbons $(\mathrm{HC})$, oxides of nitrogen $\left(\mathrm{NO}_{\mathrm{x}}\right)$, carbon monoxide $(\mathrm{CO})$ and carbon dioxide $\left(\mathrm{CO}_{2}\right)$. The vehicle emissions verification program requires the measurement of the vehicles tail-pipe emissions together with various visual checks of the vehicles principal emission control components. The cut-points are established for each contaminant based on two main criteria; the technical feasibility of achieving the desired level of emissions from the different vehicle specifications that are found in the population and the reduction that is required to reach and maintain an acceptable air quality within the city.

For all these reasons it is understood the urgency of seeking alternative technologies to avoid situations arise serious in the life of mankind and the entire biosphere. Sorbent-based processes for gas storage, separation, and purification have been the subjects of many research and studies during the past 50 years. Carbonaceous materials such as active carbon [9] [10] and carbon fiber [11] [12] have widely used in the gas sorption processes. Nanotechnology is nowadays one of the most important trends in science, perceived as one of the key technologies of the present century, its applications are variously. Nanotechnology includes the production of novel and revolutionary materials of the size of $100 \mathrm{~nm}$ or even smaller. Carbon nanotubes (CNTs) are part of these novel materials. In the recent years, one of the innovative proposals for controlling pollutant emissions are CNTs due to their distinctive chemical and physical properties like high BET area which enable them to be used in many applications, such as a new type of sorbent for environmental applications [13]-[20]. Recently, nanotube filter was successfully created and utilized to remove the biological agents from the water with filtration efficiency [21] and removing bioaerosols [22]. However, carbon nanotubes filter has not been evaluated in removing air pollutants of mobile sources despite its relevant advantages. In this study, carbon nanotubes filter were prepared by depositing carbon nanotubes on to membrane support of different materials with pore sizes of $10 \mathrm{~mm}$. The removal efficiencies of the CNTs filters prepared were investigated when collecting air pollutants of car exhausts. To our best knowledge, this study report the use of CNTs filter in removing air pollutants of mobile sources and the information provided here is useful both in air pollutants study and air pollution control measures.

\section{Experimental Methods}

\subsection{Material and Method}

Commercially available CNTs were provided by the Dr. Carlos Velasco and Dra. Ana Laura Martínez-Hernández from the Applied Physics and Center for Ad- 
vanced Technology in the UNAM Campus Juriquilla Querétaro, México. The physical properties of CNTs were obtained using different techniques.

\subsection{Physicochemical Characterization of CNTs}

The CNTs were characterized after and before that air pollutants sorption process, for techniques such as Scanning Electron Microscopy (SEM), Energy Dispersive Spectrometry (EDS), X-ray Diffraction (XRD) and Brunauer, Emmett and Teller (BET), most common method used to describe specific surface area to compare the physicochemical differences.

\subsubsection{Morphology and Elemental Composition}

Scanning Electron Microscopy (SEM) was used to determine the morphology of the carbon nanotubes through a scanning electron microscope, model JEOL $5900 \mathrm{LV}$, at $25 \mathrm{kV}$. The samples were mounted on an aluminium holder. In all cases, the images were obtained with a backscattered electron detector. Energy $\mathrm{X}$-ray Dispersion Spectroscopy (EDS) determined the semi-quantitative elemental chemical compositions of the samples with an EDAX-4 spectrometer.

Transmission Electron Microscopy (TEM) is the most important and reliable technique for correctly identifying the nature and the form of carbon nanomaterials in academic research and in industry. The information provided by TEM directly reveals both the surface and the intrinsic structure of the nanotube [23]. The observation for this research was carried out with a JEOL JEM-2010 TEM operating at $400 \mathrm{kV}$.

\subsubsection{Crystalline Components}

Compounds were identified by comparing the diffraction patterns to the Joint Committee on Powder Diffraction Standards (JCPDS) using conventional methods An X-ray diffraction analysis was performed for CNTs. The samples were placed in a holder of Lucite and then on the goniometer of the diffractometer (Siemens D-5000 diffractometer with a copper anode X-ray tube with $\lambda=$ $1.543 \AA$ ). $K \alpha$ radiation was selected with a diffracted beam monochromator at 25 $\mathrm{kV}$ and $2 \theta$ steps of $0.02^{\circ}$ for $50 \mathrm{~min}$ to acquire X-ray patterns from $4^{\circ}$ to $70^{\circ}$, with high enough intensities to achieve the lines to identify in angle $2 \theta$ the mineral components of the analysed material. Compounds were identified by comparing the diffraction patterns to the Joint Committee on Powder Diffraction Standards (JCPDS) using conventional methods [24].

\subsubsection{Thermal Stability}

$5 \mathrm{mg}$ of the samples were placed directly into platinum crucible, and the analysis was carried out under $\mathrm{N}_{2}$ flow at the heating rate of $10^{\circ} \mathrm{C} \mathrm{min}^{-1}$, with the temperature ranging from room temperature up to $950^{\circ} \mathrm{C}$ using a TGA-TDA 51 TA Instruments Thermo gravimetric Analyser.

\subsubsection{Specific Surface}

Specific surface area (SSA, $\left.\mathrm{m}^{2} \mathrm{~g}^{-1}\right)$ were determined for both dry and degassed 
natural carbon nanotubes using a multipoint $\mathrm{N}_{2}$ adsorption/desorption BrunauerEmmett-Teller (BET) method at room temperature in a Micrometrics BEL Japan INC surface area analyser.

\subsubsection{Raman Studies}

Raman spectroscopy is one of the most powerful tools for characterization of CNTs. Without sample preparation, a fast and nondestructive analysis is possible. All allotropic forms of carbon are active in Raman spectroscopy [25], and the position, width, and relative intensity of bands are modified according to the carbon forms [26]. The Raman analysis was carried out using a Horiba JobinYvon spectrometer, HR Lab Ram 800. The laser was used to excite the sample, 532 $\mathrm{nm}$. All the measurements were performed at room temperature.

\subsection{Preparation of CNTs Filters}

Removed system was built as presented in Figure 1, the filter was made of stainless steel with standard diameter of $0.05 \mathrm{~m}$, inside it, on each side there was paper whatman No. 44 and $1 \mathrm{~g}$ of packed bed of CNTs. One of the most important features of this apparatus is its direct flow measurement and temperature of air pollutants before and after passing through the CNTs filter. The apparatus was put in exit tail pipe to obtain each component of gaseous emissions, the results of sorption experiments were obtained by gas analyser of one verificenter.

\subsubsection{Interaction CNTs-Mobile Emissions}

A study in 2009, realized by the Center for Sustainable Transport in Mexico, found that in the Toluca city, the car brands: Nissan-Tsuru 1997, 1999, 2008, Chevrolet-Chevy 1998, Chevrolet-Corsa 2007, have more presence and $87 \%$ of the vehicles are personal and private and four-fifths of them run every day. For this reason in it investigation, the vehicles were randomly selected and were used five cars of these brands. The experiments were carried out in the verificenter

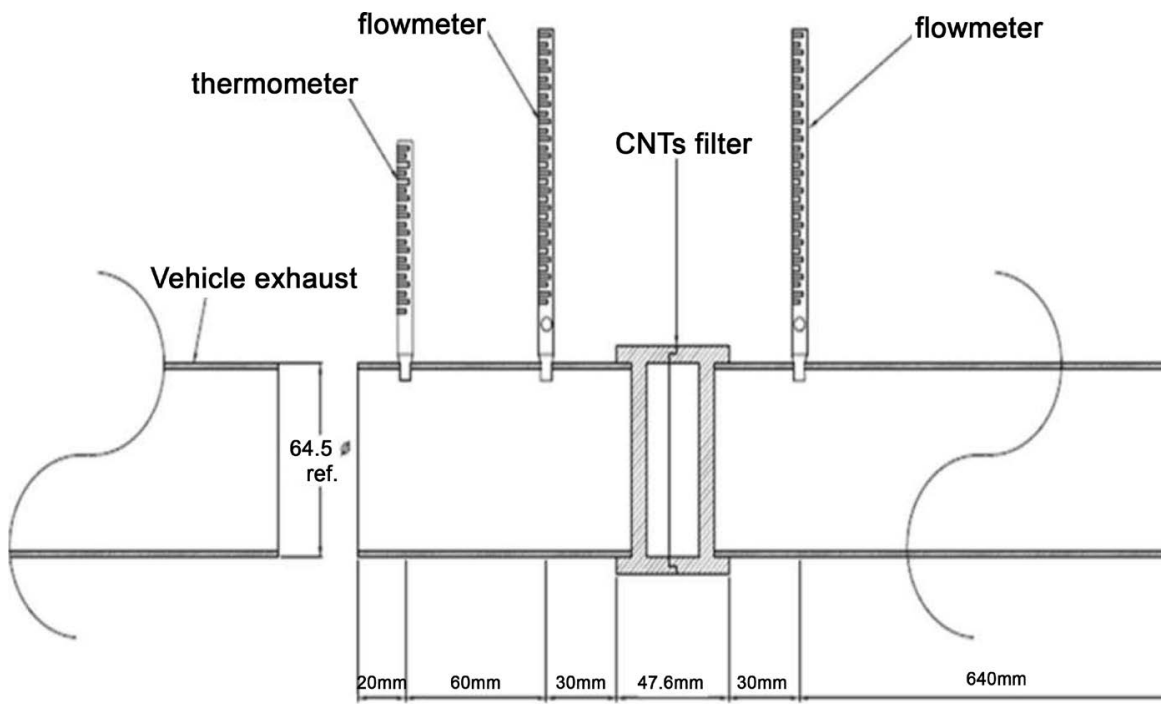

Figure 1. Experimental setup used for testing the removal efficiencies of CNTs filter. 
TO-913 Macrover Auto SAQ. S.A. de C.V., located in Ignacio Comonfort Avenue, Santa Ana Tlapaltitlán, Toluca, México. The car emissions of hydrocarbons $(\mathrm{HC})$, oxides of nitrogen $\left(\mathrm{NO}_{\mathrm{x}}\right)$, carbon monoxide $(\mathrm{CO})$ and carbon dioxide $\left(\mathrm{CO}_{2}\right)$, were verified according to program.

\subsubsection{Removal Efficiencies of CNTs Filter}

In this study, the concentrations of air pollutants after passing through the CNTs filter were calculated using the following equation [22]:

$$
\text { Removal efficiency of CNT filter }=\left(1-\frac{\text { Cwith-CNTs }}{\text { Cwithout-CNTs }} \times 100 \%\right)
$$

where $\mathrm{C}_{\text {with-CNTs }}$ is the flow of air pollutants after passing through CNT filters, and $\mathrm{C}_{\text {without-CNTs }}$ is the flow of air pollutants passing through membrane supports without CNTs loading.

\section{Results and Discussion}

\subsection{Physicochemical Characterization of CNTs by Several Techniques}

\subsubsection{Morphology and Elemental Composition (SEM \& TEM)}

\section{1) Scanning Electron Microscopy before sorption process}

The carbon nanotubes analysed in this work were colour black. The SEM image 20,000 magnification for CNTs is shown in Figure 2(a), in this can be observed that the bulk of the material is mainly constituted by fibbers; the material has a variety in diameter from 25 to $130 \mathrm{~nm}$ and 15 to $50 \mu \mathrm{m}$ in length.
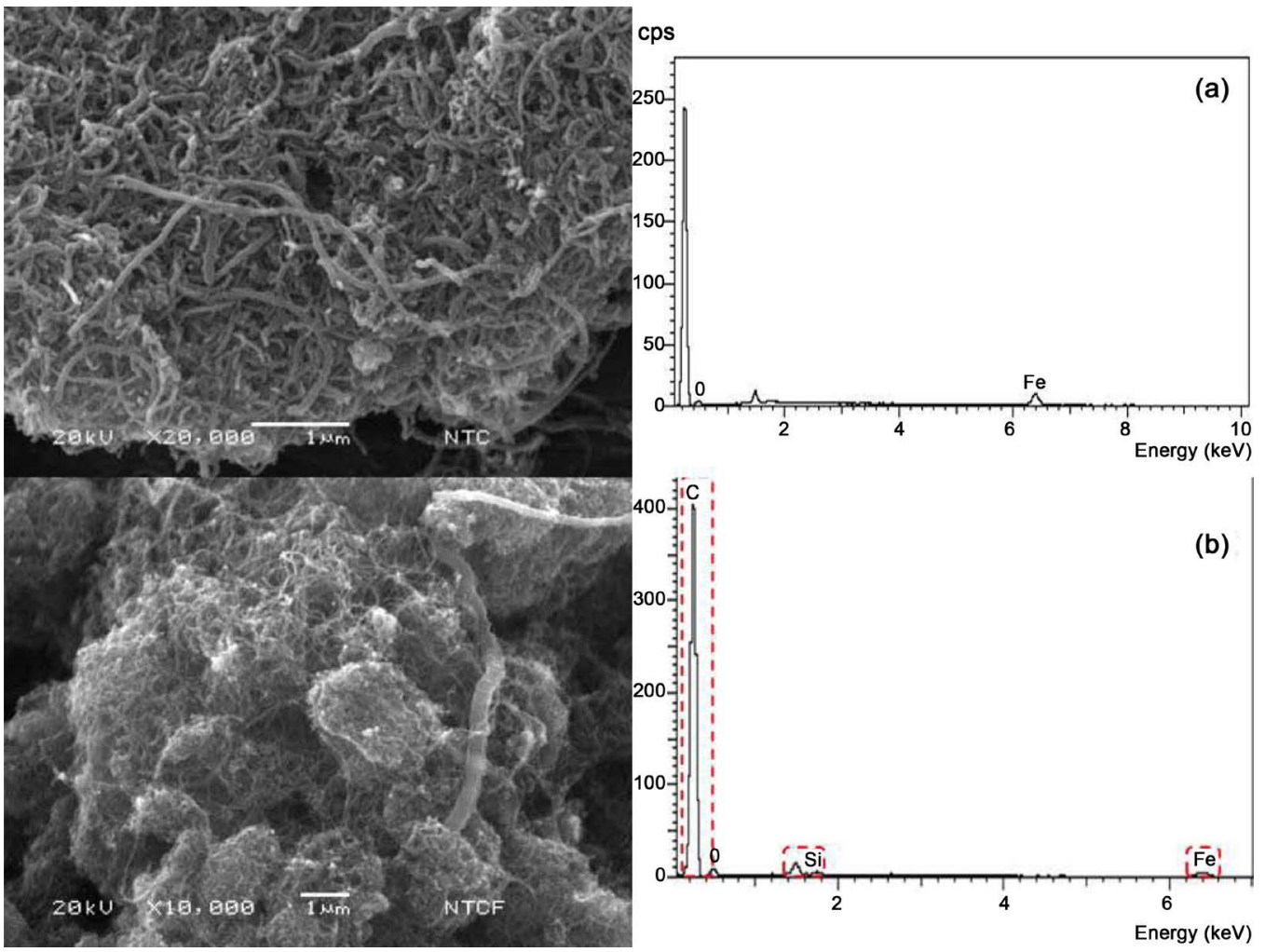

Figure 2. SEM image and EDS of carbon nanotubes (a) Before and (b) After sorption process. 
In conjunction with electron microscopy, elemental chemical composition was determined. The identification of surface feature was performed by qualitative EDS analyses. The EDS results are: for the CNTSs were found: C (91.29\%), $\mathrm{O}(6.23 \%)$ and $\mathrm{Fe}(2.48 \%)$. In this cases iron nanoparticles were used as the catalyst, for this the presence or iron in this percentage.

2) Scanning Electron Microscopy after sorption process

Below are the micrographs of the CNTS used in sorption of gaseous pollutant of exhaust from mobile sources, where it is observed that the morphology of the CNTS representative is unchanged, Figure 2(b), also in chemical composition, where in the initial percentage of unchanged: $82.70 \% \mathrm{C}, 15.66 \% \mathrm{O}, 1.24 \% \mathrm{Fe}$, however was found the presence of silicon $(\mathrm{Si})$, although at a low concentration of $0.38 \%$.

\section{3) Transmission Electron Microscopy analysis}

These studies confirm the collected material consists of multi-walled carbon nanotubes (MWCNTs), with the dominant tube diameter in the range $72.5 \mathrm{~nm}$ with length $50 \mu \mathrm{m}$ and the inter-tube spacing is of $0.34 \mathrm{~nm}$, Figure 3.

\subsubsection{X-Ray Diffraction (XRD)}

According to the Joint Committee on Powder Diffraction Standard (JCPDS, card
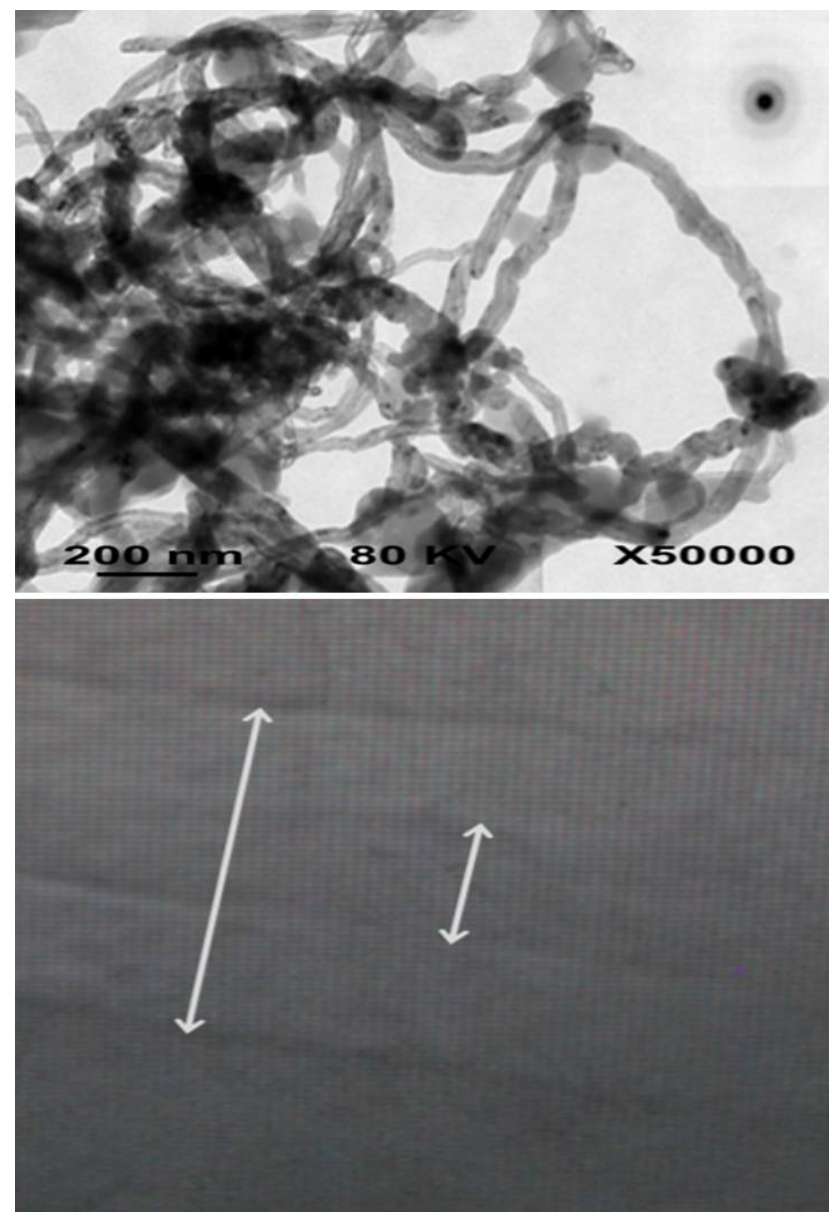

Figure 3. TEM images of CNTs. Internal and external diameter range: 2 - $20 \mathrm{~nm}$. 


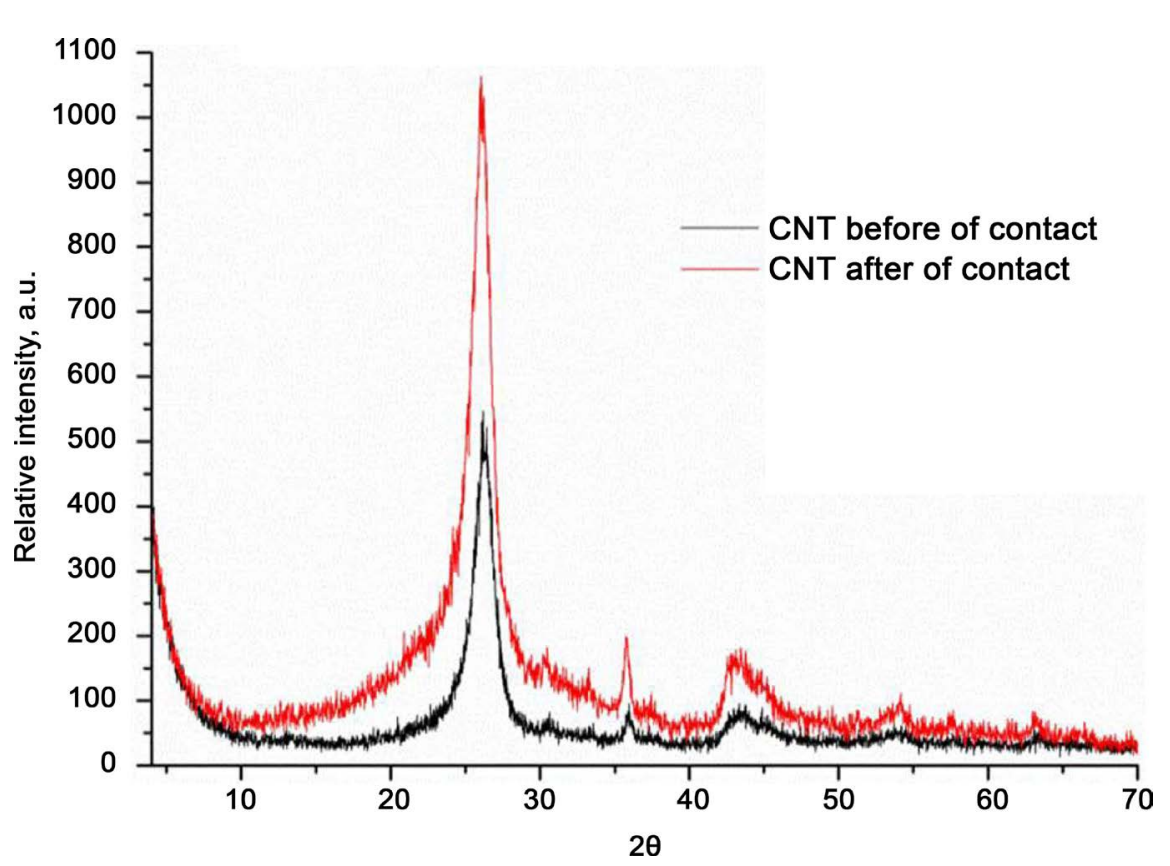

Figure 4. XRD patterns of CNTs before and after of contact with air pollutants.

01-075-2078), the main mineral compound present in CNTs is graphite. The intensity of the strongest peak to $26^{\circ}$ for graphite is considered to represent the crystalline compound, and the intensity between $43^{\circ}$ and $46^{\circ}$ represents the background due to amorphous components. This behaviour indicates that the material does not suffer modification of its structure, Figure 4.

\subsubsection{Thermal Stability}

Thermal analysis methods are useful for identifying relative changes due to processing. It was used to study the degree of CNTs purification [25]. The loss of weight were from 25 to $800^{\circ} \mathrm{C}$ of $3.78 \%$, from 800 to $870^{\circ} \mathrm{C}$ of $0.46 \%$, from 870 to $900^{\circ} \mathrm{C}$ of $2.34 \%$ and 900 to $1000^{\circ} \mathrm{C}$ of $3.71 \%$. In agreement to the results, it is confirmed that the CNTs do not present a high loss of weight (10.5\%), Figure 5.

\subsubsection{Specific Surface of Carbon Nanotubes}

The total surface area (TSA) determined from classical BET method by physisorption of nitrogen at $78 \mathrm{~K}$ is presented. The CNTs showed that specific surface area is of $153 \mathrm{~m}^{2} / \mathrm{g}$, the total pore volume of $0.9534 \mathrm{~cm}^{3} \mathrm{~g}^{-1}$ and an average pore diameter of $24.931 \mathrm{~nm}$, classifying to the CNTs as mesoporous material (2 to $50 \mathrm{~nm}$ ) according to the IUPAC classification. The data were analysed using the Langmuir adsorption model. It was concluded that CNTs had greater adsorption capacity, Figure 6.

\subsubsection{Raman Spectroscopy Studies of Carbon Nanotubes}

The Raman spectrum of CNTs sample is indicated in Figure 7. As shown, the band at $1580 \mathrm{~cm}^{-1}$ ( $\mathrm{G}$ band) is due to tangential stretching of the carbon atoms in a two dimensional hexagonal lattice as a graphite sheet, this band reveals the presence of multi-walled nanotubes in the sample. The peak centered at around 


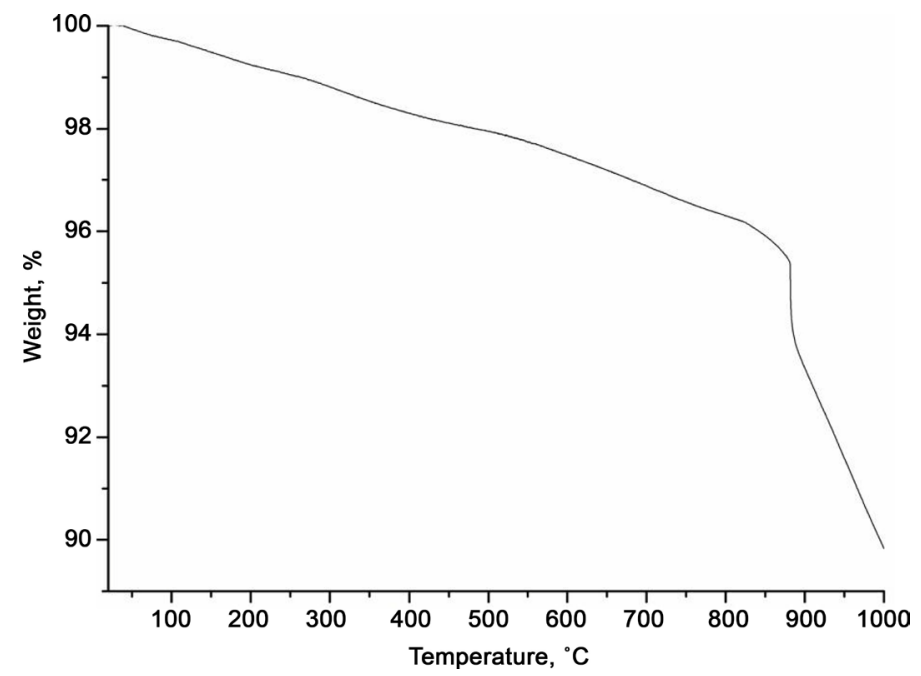

Figure 5. Thermogravimetric analysis (TGA) has demonstrated that nanotubes (CNTs) are stable.

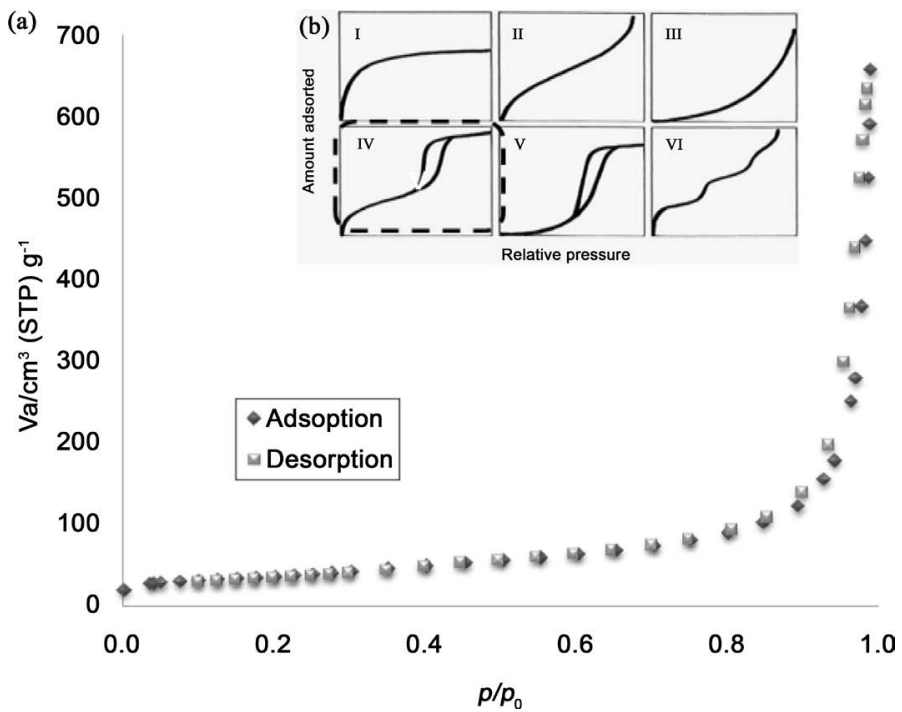

Figure 6. Adsorption and desorption isotherms of CNTs.

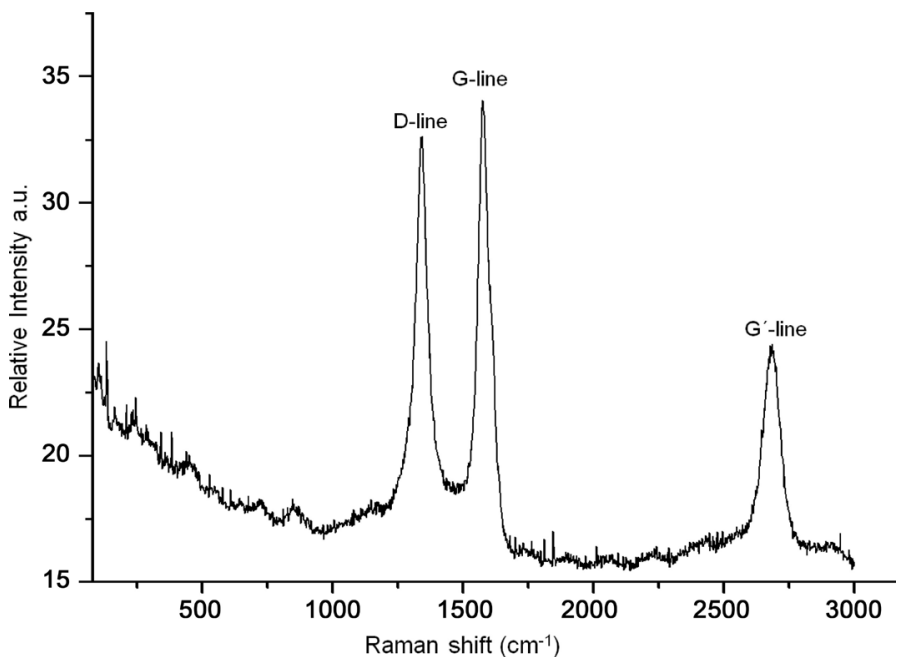

Figure 7. Raman spectrum of carbon nanotubes. 
$1349 \mathrm{~cm}^{-1}$ (D-band) indicates disturbances on the hybridization of $\mathrm{sp}^{2}$ carbon atoms and has its overtone at $2681 \mathrm{~cm}^{-1}$, is mainly due to the presence of amorphous carbon and defects in the sample [27]. These two positions are close to $1346 \mathrm{~cm}^{-1}$ and $1578 \mathrm{~cm}^{-1}$ which have been reported in the literature as features for multi-walled nanotubes concentric hexagonal lattice [28].

\subsection{Removal Efficiencies of CNT Filters}

\subsubsection{CNTs BET before Sorption Process}

Table 1 and Table 2 show the vehicle models that were tested, presents the average removal efficiencies obtained, there can be seen that reduction of air pollutants using the sorption device packaged with the CNTS it is different for each vehicle.

For the tests conducted Corsa 2007, the flow was maintained at $80 \mathrm{~mL} / \mathrm{min}$, the temperature varied between $40^{\circ} \mathrm{C}$ and $50^{\circ} \mathrm{C}$. For $1998 \mathrm{Chevy}$, the flow was $110 \mathrm{~mL} / \mathrm{min}$ and the temperature at $70^{\circ} \mathrm{C}$, to Nissan models 1997 and 1999, the flow varied between 85 and $90 \mathrm{~mL} / \mathrm{min}$, the temperature was $85^{\circ} \mathrm{C}, 2008$ model presents a flow of $40 \mathrm{~mL} / \mathrm{min}$, and the temperature was $40^{\circ} \mathrm{C}$.

The maximum permissible emission of pollutants applies to vehicles that are

Table 1. Comparison of average emission results.

\begin{tabular}{|c|c|c|c|c|c|c|}
\hline Vehicle & Model Year & & & unfiltered & with filter & \% Rem. \\
\hline \multirow{4}{*}{ Corsa } & \multirow{4}{*}{2007} & $\mathrm{CO}$ & $\% \mathrm{Vol}$ & 0.19 & 0.02 & 89 \\
\hline & & $\mathrm{HC}$ & ppm & 13 & 5 & 62 \\
\hline & & $\mathrm{CO}_{2}$ & $\% \mathrm{Vol}$ & 15.90 & 15.80 & 0.6 \\
\hline & & $\mathrm{NO}_{\mathrm{x}}$ & ppm & 335 & 16 & 89 \\
\hline \multirow{4}{*}{$\begin{array}{c}\text { Nissan } \\
\text { Tsuru }\end{array}$} & \multirow{4}{*}{1997} & $\mathrm{CO}$ & $\% \mathrm{Vol}$ & 0.66 & 0.57 & 14 \\
\hline & & $\mathrm{HC}$ & $\mathrm{ppm}$ & 370.4 & 128 & 65 \\
\hline & & $\mathrm{CO}_{2}$ & $\% \mathrm{Vol}$ & 11.52 & 11.06 & 4 \\
\hline & & $\mathrm{NO}_{\mathrm{x}}$ & ppm & 108 & 83 & 23 \\
\hline \multirow{4}{*}{$\begin{array}{c}\text { Nissan } \\
\text { Tsuru }\end{array}$} & \multirow{4}{*}{1999} & $\mathrm{CO}$ & $\% \mathrm{Vol}$ & 270 & 160 & 41 \\
\hline & & $\mathrm{HC}$ & ppm & 134 & 101 & 25 \\
\hline & & $\mathrm{CO}_{2}$ & $\% \mathrm{Vol}$ & 14.19 & 10.06 & 29 \\
\hline & & $\mathrm{NO}_{\mathrm{x}}$ & ppm & 468 & 6 & 57 \\
\hline \multirow{4}{*}{$\begin{array}{c}\text { Nissan } \\
\text { Tsuru }\end{array}$} & \multirow{4}{*}{2008} & $\mathrm{CO}$ & $\% \mathrm{Vol}$ & 0.52 & 0.02 & 96 \\
\hline & & $\mathrm{HC}$ & ppm & 6 & 5 & 17 \\
\hline & & $\mathrm{CO}_{2}$ & $\% \mathrm{Vol}$ & 11.71 & 8.9 & 24 \\
\hline & & $\mathrm{NO}_{\mathrm{x}}$ & ppm & 19.2 & 5.6 & 70.8 \\
\hline \multirow{4}{*}{$\begin{array}{c}\text { Chevrolet } \\
\text { Chevy }\end{array}$} & \multirow{4}{*}{1998} & $\mathrm{CO}$ & $\% \mathrm{Vol}$ & 3 & 0 & 100 \\
\hline & & $\mathrm{HC}$ & $\mathrm{ppm}$ & 2.4 & 0.02 & 99 \\
\hline & & $\mathrm{CO}_{2}$ & $\% \mathrm{Vol}$ & 14.69 & 14.02 & 4.6 \\
\hline & & $\mathrm{NO}_{\mathrm{x}}$ & ppm & 15 & 3 & 80 \\
\hline
\end{tabular}


Table 2. Comparison of average emission results, fast idle.

\begin{tabular}{|c|c|c|c|c|c|c|}
\hline Vehicle & Model Year & \multicolumn{2}{|c|}{ Gases } & unfiltered & With filter & \% Rem. \\
\hline \multirow{4}{*}{ CORSA } & \multirow{4}{*}{2007} & $\mathrm{CO}$ & $\% \mathrm{Vol}$ & 0.02 & 0.02 & 0 \\
\hline & & $\mathrm{HC}$ & ppm & 12 & 8 & 33 \\
\hline & & $\mathrm{CO}_{2}$ & $\% \mathrm{Vol}$ & 16 & 15.80 & 1 \\
\hline & & $\mathrm{NO}_{\mathrm{x}}$ & ppm & 180 & 19 & 89 \\
\hline \multirow{4}{*}{$\begin{array}{c}\text { Nissan } \\
\text { Tsuru }\end{array}$} & \multirow{4}{*}{1997} & $\mathrm{CO}$ & $\% \mathrm{Vol}$ & 0.69 & 0.69 & 0 \\
\hline & & $\mathrm{HC}$ & ppm & 173.2 & 159.8 & 8 \\
\hline & & $\mathrm{CO}_{2}$ & $\%$ Vol & 11.96 & 11.89 & 0.6 \\
\hline & & $\mathrm{NO}_{\mathrm{x}}$ & ppm & 99.6 & 30.4 & 70 \\
\hline \multirow{4}{*}{$\begin{array}{c}\text { Nissan } \\
\text { Tsuru }\end{array}$} & \multirow{4}{*}{1999} & $\mathrm{CO}$ & $\% \mathrm{Vol}$ & 0.05 & 0.04 & 20 \\
\hline & & $\mathrm{HC}$ & ppm & 7 & 6.9 & 2 \\
\hline & & $\mathrm{CO}_{2}$ & $\% \mathrm{Vol}$ & 12.4 & 9.7 & 22 \\
\hline & & $\mathrm{NO}_{\mathrm{x}}$ & ppm & 456 & 110 & 76 \\
\hline \multirow{4}{*}{$\begin{array}{c}\text { Nissan } \\
\text { Tsuru }\end{array}$} & \multirow{4}{*}{2008} & $\mathrm{CO}$ & $\% \mathrm{Vol}$ & 0.5 & 0.02 & 96 \\
\hline & & $\mathrm{HC}$ & ppm & 8 & 6.7 & 16 \\
\hline & & $\mathrm{CO}_{2}$ & $\% \mathrm{Vol}$ & 16 & 11.02 & 31 \\
\hline & & $\mathrm{NO}_{\mathrm{x}}$ & ppm & 19 & 17.7 & 7 \\
\hline \multirow{4}{*}{$\begin{array}{c}\text { Chevrolet } \\
\text { Chevy }\end{array}$} & \multirow{4}{*}{1998} & $\mathrm{CO}$ & $\% \mathrm{Vol}$ & 0.7 & 0.44 & 37 \\
\hline & & $\mathrm{HC}$ & ppm & 128 & 115 & 10 \\
\hline & & $\mathrm{CO}_{2}$ & $\% \mathrm{Vol}$ & 18.5 & 11 & 41 \\
\hline & & $\mathrm{NO}_{\mathrm{x}}$ & ppm & 84 & 6 & 93 \\
\hline
\end{tabular}

evaluated under this test, are given by the Mexican Official Standards NOM041-SEMARNAT-1999 [29] and NOM-050-SEMARNAT-1993 [30] that apply to gasoline vehicles.

As shown in Table 1, the summary Comparison of Average Emission Results, was significantly higher variability was observed for the removal efficiency of the MWNT filters when collecting $\mathrm{CO}$ and $\mathrm{NO}_{2}$. Nonetheless, the average removal efficiency of the CNT filters were observed for all air pollutants, but the removal efficiency was less. For the first test, the emissions were taken when vehicles were accelerated to $4 \mathrm{~km} / \mathrm{h}$.

Table 2 shows summary Comparison of Average Emission Results for the test fast idle $(40 \mathrm{~km} / \mathrm{h})$ for different vehicles, shows the removal efficiencies of MWNT filters when collecting four air pollutants, $\mathrm{CO}, \mathrm{HC}, \mathrm{CO}_{2}, \mathrm{NO}_{\mathrm{x}}$. However the removal efficiency for the CNT, was found significantly higher for NOx in all vehicles.

Nissan vehicles presented variability in its results; this is because they are different models. However the 2008 model had higher removal efficiency of the contaminants. The vehicle Corsa 2007 Chevy 1998 showed higher removal efficiency for $\mathrm{NO}_{\mathrm{x}}$. 


\subsubsection{CNTs BET after Sorption Process}

After the removal, the CNTs showed that decrease $16 \%$ in BET surface area, it was $128 \mathrm{~m}^{2} \mathrm{~g}^{-1}$. The total pore volume of $0.9999 \mathrm{~cm}^{3} \mathrm{~g}^{-1}$ and an average pore diameter of $31.06 \mathrm{~nm}$, according to the IUPAC classification as mesoporous material $(2$ to $50 \mathrm{~nm}$ ). The data were analysed using the Langmuir adsorption model. It was concluded that CNTs do not showed changes in adsorption capacity. Nitrogen adsorption isotherm of the CNTS, after sorption, follows the behavior of type IV and $\mathrm{V}$ of the physical adsorption isotherms IUPAC.

\section{Conclusions}

The CNTs were identified such as multi-called material and they were composed of carbon, $91.29 \%$ and oxygen, $6.23 \%$. The characterization of these showed that the bulk is mainly constituted by fibbers. XRD confirm the presence of graphite. They are formed of two layers according Raman studies.

They have a specific surface area of $153 \mathrm{~m}^{2} / \mathrm{g}$ classifying them as mesoporous material, but after removal gases, the specific surface area decreases to $128 \mathrm{~m}^{2} / \mathrm{g}$, showing that gases were sorbed. CNTs can be used to remove gases harmful to the health of mobile sources, but their efficiency depends of different variants.

\section{Acknowledgements}

We are grateful to the personal of RAMAT and ININ for their technical help: SEM, TEM, BET and TGA; and to Dr. C. Velasco-Santos and Dra. Ana Laura Martínez-Hernández from the Instituto Tecnológico de Querétaro. Av. Tecnológico S/N esquina Gral. Mariano Escobedo, Colonia Centro Histórico. C.P. 76000. México. Centro de Física Aplicada y Tecnología Avanzada CFATAUNAM Campus Juriquilla Querétaro for the material.

\section{References}

[1] Chabaan, F.B., Nuwayhid, I. and Djoundourian, S. (2001) A Study of Social and Economic Implications of Mobile Sources on Air Quality in Lebanon. Transportation Research Part D, 6, 347-355. https://doi.org/10.1016/S1361-9209(01)00004-9

[2] Shohreh, F., Masoud Vesali, N., Mona, C. and Jalal, H. (2011) Improving $\mathrm{CO}_{2} / \mathrm{CH}_{4}$ Adsorptive Selectivity of Carbon Nanotubes by Functionalization with NitrogenContaining Groups. Chemical Engineering Research and Design, 89, 1669-1675. https://doi.org/10.1016/j.cherd.2010.10.002

[3] Kampa, M. and Castanas, E. (2008) Human Health Effects of Air Pollution. Environmental Pollution, 151, 362-367. https://doi.org/10.1016/j.envpol.2007.06.012

[4] Katsouyanni, K. (2003) Ambient Air Pollution and Health. British Medical Bulletin, 68, 143-156. https://doi.org/10.1093/bmb/ldg028

[5] Joellen, L. (2007) Air Pollution Combustion Emissions: Characterization of Causative Agents and Mechanisms Associated with Cancer, Reproductive, and Cardiovascular Effects. Mutation Research, 636, 95-133. https://doi.org/10.1016/j.mrrev.2007.08.003

[6] Guihua, W., Song, B. and Joan, M.O. (2009) Identifying Contributions of On-Road 
Motor Vehicles to Urban Air Pollution Using Travel Demand Model Data. Transportation Research Part D, 14, 168-179. https://doi.org/10.1016/j.trd.2008.11.011

[7] Daponte, C.A., Ordóñez, M.J., Arribas, F., Cambra, K., Iñiguez, C., Cañada, A., Barceló, M.A., Bellido, J., Guillén, J.J., Ballester, F, Sáez, M., Pérez, H.S. and Taracido, T.M. (2003) Relación a corto plazo de la contaminación atmosférica y la mortalidad en 13 ciudades españolas. Medicina Clínica, 121, 684-689. https://doi.org/10.1016/S0025-7753(03)74063-9

[8] Jes, F. (2009) Air Pollution in the Last 50 Years-From Local to Global. Original Atmospheric Environment, 43, 13-22. https://doi.org/10.1016/j.atmosenv.2008.09.061

[9] Somy, A., Mehrnia, M.R., Delavari-Amrei, H., Ghanizadeh, A. and Safari, M. (2009) Adsorption of Carbon Dioxide Using Impregnated Activated Carbon Promoted by Zinc. International Journal of Greenhouse Gas Control, 3, 249-254. https://doi.org/10.1016/j.ijggc.2008.10.003

[10] Budaeva, A.D. and Zoltoev, E.V. (2010) Porous Structure and Sorption Properties of Nitrogen-Containing Activated Carbon. Fuel, 89, 2623-2627.

https://doi.org/10.1016/j.fuel.2010.04.016

[11] Thiruvenkatachari, R., Su, S., An, H. and Yu, X.X. (2009) Post Combustion $\mathrm{CO}_{2}$ Capture by Carbon Fibre Monolithic Adsorbents. Progress in Energy and Combustion Science, 35, 438-455. https://doi.org/10.1016/j.pecs.2009.05.003

[12] Arrigo, R., Havecker, M., Wrabetz, S., Blume, R., Lerch, M., McGregor, J., Parrott, E.P.J., Zeitler, J.A., Gladden, L.F., Knop-Gericke, A., Schlogl, R. and Su, D.S. (2010) Tuning the Acid/Base Properties of Nanocarbons by Functionalization via Amination. Journal of the American Chemical Society, 132, 9616-9630. https://doi.org/10.1021/ja910169v

[13] Cinke, M., Li, J., Charles, W., Bauschlicher, J., Ricca, A. and Meyyappan, M. (2003) $\mathrm{CO}_{2}$ Adsorption in Single-Walled Carbon Nanotubes. Chemical Physics Letters, 376, 761-766. https://doi.org/10.1016/S0009-2614(03)01124-2

[14] Liang, Q., Li, Q., Gao, L. and Yu, Z.L. (2001) Carbon Nanotubes Prepared from CO on Pre-Reduced $\mathrm{La}_{2} \mathrm{NiO}_{4}$ Perovskite Precursor. Materials Research Bulletin, 36, 471-477. https://doi.org/10.1016/S0025-5408(00)00480-3

[15] De Jong, K. and Geus. J. (2000) Carbon Nanofibers: Catalytic Synthesis and Applications. Catalysis Reviews-Science and Engineering, 42, 481-510. https://doi.org/10.1081/CR-100101954

[16] Nunes, A., Al-Jamal, K., Nakajima, T., Hariz, M. and Kostarelos, K. (2012) Application of Carbon Nanotubes in Neurology: Clinical Perspectives and Toxicological Risks. Archives of Toxicology, 86, 1009-1020. https://doi.org/10.1007/s00204-012-0860-0

[17] Ju-Nam, Y. and Lead, J.R. (2008) Manufactured Nanoparticles: An Overview of Their Chemistry, Interactions and Potential Environmental Implications. Science of the Total Environment, 400, 396-414.

https://doi.org/10.1016/j.scitotenv.2008.06.042

[18] Shen, Y. and Bai, J. (2010) A New Kind $\mathrm{CO}_{2} / \mathrm{CH}_{4}$ Separation Material: Open Ended Nitrogen Doped Carbon Nanotubes Formed by Direct Pyrolysis of Metal Organic Frameworks. Chemical Communications, 46, 1308-1310. https://doi.org/10.1039/b913820j

[19] Takagi, H., Hatori, H., Soneda, Y., Yoshizawa, N. and Yamada, Y. (2004) Adsorptive Hydrogen Storage in Carbon and Porous Materials. Materials Science and En- 
gineering: $B, 108,143-147$. https://doi.org/10.1016/j.mseb.2003.10.095

[20] Yamada, Y. and Ozaki, J. (2003) Nanoporous Carbons. In: Nalwa, H.S., Ed., Encyclopedia of Nanoscience and Nanotechnology, American Scientific Publishers, Los Angeles, CA, 237-262.

[21] Brady-Estévez, A.S., Kang, S. and Elimelech, M. (2008) A Single-Walled-Carbon-Nanotube Filter for Removal of Viral and Bacterial Pathogens. Small, 4, 481484. https://doi.org/10.1002/smll.200700863

[22] Guan, T. and Yao, M. (2010) Use of Carbon Nanotube Filter in Removing Bioaerosols. Journal of Aerosol Science, 4, 611-620.

https://doi.org/10.1016/j.jaerosci.2010.03.002

[23] Wang, Z.L., Poncharal, P. and de Heer, W.A. (2000) Nanomeasurements of Individual Carbon Nanotubes by in Situ TEM. Pure and Applied Chemistry, 72, 209219. https://doi.org/10.1351/pac200072010209

[24] Bayliss, P. (1986) Mineral Powder Diffraction File Date Book: Swarthmore, PA, Joint Committee on Powder Diffraction Standards (JCPDS).

[25] Arepalli, S., Nikolaev, P., Gorelik, O., Hadjiev, V.G., Holmes, W., Files, B. and Yowell, L. (2004) Protocol for the Characterization of Single-Wall Carbon Nanotube Material Quality. Carbon, 42, 1783-1791.

https://doi.org/10.1016/j.carbon.2004.03.038

[26] Ferrari, A. and Robertson, J. (2000) Interpretation of Raman Spectra of Disordered and Amorphous Carbon. Physical Review B, 61, 14095.

https://doi.org/10.1103/PhysRevB.61.14095

[27] Vesali-Naseh, M., Khodadadi, A.A., Mortazavi, Y., Pourfayaz, F., Alizadeh, O. and Maghrebi, M. (2010) Fast and Clean Functionalization of Carbon Nanotubes by Dielectric Barrier Discharge Plasma in Air Compared to Acid Treatment. Carbon, 48, 1369-1379. https://doi.org/10.1016/j.carbon.2009.12.027

[28] Zhang, H. B., Lin, G. D., Zhou, Z. H., Dong, X. and Chen, T. (2002) Raman Spectra of MWCNTs and MWCNT Based $\mathrm{H}_{2}$-Adsorbing System. Carbon, 40, 2429-2436. https://doi.org/10.1016/S0008-6223(02)00148-3

[29] Mexican Official Standards NOM-041-SEMARNAT-1999.

[30] NOM-050-SEMARNAT-1993. 